\title{
Competitors' cost analysis: a study with companies of the Brazilian sugarcane industry
}

\author{
Salete Verginia Fontana Baiochi * , Elizandra Severgnini, Maurilio José \\ Batista, Katia Abbas, Kelly Cristina Mucio Marques
}

University State Maringá, Brazil

Received August 13, 2016; accepted May 31, 2018

Available online November 14, 2018

\begin{abstract}
The paper's goal is to analyze the main predictors of the cost of goods sold based on the Competitors' Cost Analysis Technique and to verify the influence of capital structure and the capital asset on the cost of the goods sold. We collected data from Economatica and Fundamentus databases. We extracted the data from quarterly Balance Sheets and Income Statements by Brazilians companies, such as Biosev S.A., Cosan S.A. and São Martinho S.A. We used the Cost of Goods Sold (CGS) as the dependent variable in two regression models and for the explanatory variables, we used revenue, capital assets and capital structure measured by the total liability divided by total asset plus the debt-to-equity ratio. We conclude that the variable costs have the greatest influence on the cost structure of Biosev S.A. (68\% of CGS) and of Cosan S.A. (79\% of CGS). Capital structure and capital assets had an impact on the CGS. The capital assets and the total debt ratio plus the equity ratio presented a direct main effect and the debt-to-equity ratio presented a proportionally inverse effect.
\end{abstract}

JEL code: D00, D24

Keywords: Strategic Cost Management; Competitors' cost analysis; Cost determinants.

\footnotetext{
* Corresponding author.

E-mail address: : salbaiochi@yahoo.com.br (S. V. Fontana Baiochi)

Peer Review under the responsibility of Universidad Nacional Autónoma de México.
} 


\section{Resumen}

El objetivo del artículo es analizar los principales factores predictivos del costo de los bienes vendidos en base a la Técnica de análisis de costos de los competidores y verificar la influencia de la estructura de capital y el activo de capital en el costo de los bienes vendidos (COGS). Se recopilaron datos de las bases Economatica y Fundamentus. Se extrajo los datos trimestrales de los balances y estados de resultados de empresas brasileñas, como Biosev SA, Cosan SA y São Martinho SA. Utilizamos el costo de los bienes vendidos (COGS) como variable dependiente en dos modelos de regresión y para las variables explicativas, utilizamos los ingresos, los activos de capital y la estructura de capital medidos por el pasivo total dividido por el activo total más la relación deuda / capital. Se concluye que los costos variables tienen la mayor influencia en la estructura de costos de Biosev S.A. (68\% de COGS) y de Cosan S.A. (79\% de COGS). La estructura de capital y los activos de capital tuvieron un impacto en el COGS. Los activos de capital y el índice de deuda total más el índice de capital presentaron un efecto principal directo y el índice de deuda a capital presentó un efecto inversamente proporcional.

Códigos JEL: D00, D24

Palabras clave: Gestión estratégica de costos; Análisis de costos de los competidores; Determinantes del coste.

\section{Introduction}

The competition existent in the global economic makes companies pay more attention to strategic factors as a way to guarantee a competitive advantage in order to survive in business. Porter (2008a, b) presented the importance of the competitive environment in elaborating the five forces, defined as competition in the industry, bargaining power of suppliers, the threat of new entrants, bargaining power of buyers and threat of substitute products or services. In this five forces model, the competitors are pointed as the center of the relation with the other agents. Competitors are important in order to influence the market and induce decision-making so that it is strategic and capable of conducting the company to the desired success.

Strategic Cost Management (SCM) is defined as "is the application of cost management techniques so that they simultaneously improve the strategic position of a firm and reduce costs" (Cooper \& Slagmulder, 1998, p.14). By focusing on the company and its environment, strategic cost management allows the identification of strategies that once aligned to the company's cost structure, and it can unveil competitive advantage, thus contributing to the continuation of the company in the market. One dimension of SCM is termed as Competitors' Cost Analysis (Simmonds, 1982; 1986; Bromwich, 1990; Moon \& Bates, 1993; Heinen \& Hoffjan, 2005) or the Competitor-Focused Accounting (Guilding, 1999), which aims to analyze, assess, and infer information about costs through specific techniques, in order to make advantages and competitiveness possible in relation to one's competitors.

Competitors are those who seek to satisfy the same consumers, and consequently their needs, in addition to competing to obtain the necessary resources to establish competitive strategies (Cavalluzzo, Cavalluzzo \& Wolken, 2002; Dawson et al 1995). Competitors' Cost Analysis is used to develop and to follow the business strategy, mainly in relation to the costs, prices, volume and market share of competitors (Simmonds, 1981). Companies use the information from the Competitors' Cost Analysis to determine their strategy in the market in a sustainable manner (Bromwich, 1990). Therefore, this information analysis: (i) provides a detailed vision about the costs and financial situation of competitors; (ii) determines the 
company's own competitive position and (iii) predicts the competitive strategic behavior of competitors (Heinen \& Hoffjan, 2005). Competitors' Cost Analysis is strongly associated with decision-making since it includes a regular update of estimates concerning competitors' price and strategy (Guilding, 1999).

The analysis of the cause of the costs - termed as cost drivers - is the structural cause of costs (Porter, 1992). For this reason, as equally important to verifying the competitor's cost structure is verifying the cost drivers to enable comparisons and inferences that aid cost management decision-making. We emphasize that one of the difficulties of applying the Cost Analysis of Competitors is to obtain the data. (Costa, 2011) states that little has been developed regarding the creation and use of techniques to estimate and analyze costs among competitors. Considering the importance of Competitors' Cost Analysis, and the use of publicly disclosed financial statements by firms as sources of information to the analysis of competitors' cost, this paper seeks to answer the following questions: (1) What are the predictors of the cost of goods sold whilst maintaining a steady fixed cost in competing companies of the sugarcane industry in the period from 2007 to 2014 ? and; (2) What is the influence of capital structure and capital assets on the cost of goods sold?

In this paper, we analyze the sugarcane industry. This choice took place because this sector represents one of the greatest impacts on the Brazilian economy, reaching a high competitive level, with higher productivity volume and with one of lowest production costs in the world. These achievements from the sugarcane industry are due to the adoption of modern technology, since the country masters production technology in the agricultural area as well as in the industrial area (Vieira, Lima \& Braga, 2007). According to the BMF\&BOVESPA (2015a), the sugarcane industry categorizes ethanol and sugarcane as commodities. These types of product can be economically considered as a state of perfect competition, with continuous production of homogeneous goods in large scale, promoting a similarity in competition among firms (Ferraz, Kupfer \& Haguenauer, 1995).

We chose sugarcane companies based on the fact that these firms publicly disclose financial statements, in addition to showing homogeneity in their contents due to their belonging to the New Market, which according to BMF\&BOVESPA (2015b), represents the standard of differentiated corporate governance reaching transparency and governance requirements. In the last decade, the New Market has a section destined to the negotiation of companies' shares that voluntarily adopt additional corporate governance practices in addition to those required by the Brazilian Legislation, aligned to a policy of more transparent and comprehensive information disclosure.

For the purpose of this investigation, we use the conceptual and theoretical background by Casella (2008), Souza (2011) and Albanez, Bonizio and Ribeiro (2008). In addition, this paper stands out in the midst of other theoretical views. First, we do not seek to infer the competitors' costs, since Casella (2008) has already confirmed this assumption. Second, this paper aims to infer the competitors' costs through the financial statements published in different forms, which is a different perspective from the one by Souza (2011). Third, this paper advances in the Competitors' Cost Analysis literature by performing a comparative analysis of costs. Fourth, this research moves forward in the discussion and in the Competitors' Cost Analysis, specifically in three competing sectors of commodities, all of them from the sugarcane industry.

Authors in the literature point out the need for both knowledge and cost analysis of competitors (Shank, 1989; Bromwich, 1990; Shank \& Govindarajan, 1989; Cooper \& 
Slagmulder, 2004). Therefore, the result of the competitor's cost analysis may contribute to generating information about the impact of the cost variable on the cost of goods sold, as well as explaining the determinants of the cost of goods sold. Moreover, from the company standpoint, this paper contributes to management decision-making by explaining how information related to competitors is relevant in order to analyze and compare the position of competitors in relation to costs and structure. Hesford (2008, p. 18) points out that just as "accounting information is ignored or minimally used (for estimating competitors' costs)", "information on competitors' costs is important but rarely monitored" (p. 38), showing a gap in the literature. Last, this paper contributes to the discussion of Strategic Cost Management practices by presenting a way of comparing cost calculations according to the literature review.

Following the introduction, this paper is organized into four sections. The second section presents the theoretical foundations needed to ground the study. The third section presents the methodological design of the study, where we seek to clarify the way that we conducted the research. The fourth section presents the research results, as well as the analysis. Lastly, the fifth section presents the final considerations of this article, answering the proposed problematic and objectives.

\section{Theoretical framework}

In the theoretical framework, we discuss the Competitors' Cost Analysis, cost drivers and how they can predict the cost of goods sold.

\section{Competitors' cost analysis}

Firms use Strategic Cost Management in competitive markets according to data available from the cost of products (Shank, 1989; Ansari, 1997). These data are analyzed and transformed into information to implement strategic actions that reduce uncertainties (Shank \& Govindarajan, 1989). In addition, the information from the cost of products can be used to develop, map out and identify strategies aiming to create competitive advantage (Hansen \& Mowen, 2001; Shank \& Govindarajan, 1989) and guarantee improvements in the production process (e.g. quality and accessible prices) to preserve the company's continuity.

Therefore, in order for Strategic Cost Management to reach the goal of reducing costs while simultaneously strengthening the company's competitiveness (Cooper \& Slagmulder, 2003), Strategic Cost Management should be based on the Competitors' Cost Analysis (Shank \& Govindarajan, 1989; Dixon, 1998; Bhimani \& Keshtvarz, 1999; Guilding, Craves \& Tayles, 2000; Heinen \& Hoffjan, 2005). Competitors' Cost Analysis "represents a strategic application of cost modeling. At the highest level, it allows for a direct comparison of a company and one of its products or services with a direct competitor or competitive offering" (Laseter, Heckel \& Huang, 2017, p.1).

As a contribution to business management, Competitors' Cost Analysis offers firms an estimative of their competitors' costs that enables the formulation and implementation of strategic action (Souza, Marengo \& Jaroseski, 2012), the establishment of a competitive position (Heinen \& Hoffjan, 2005) and the possibility of searching for a new form of offering more value to the client. Competitors' cost analysis "includes a regularly updated forecast of competitors' unit costs (Guilding, 1999, p. 585). 
As a result, the theoretical and practical development of this theme rests with several authors who have proposed to study, analyze and identify characteristics on the costs of competitors to contribute to the expansion of knowledge. Table 1 shows the authors and the purpose of their studies.

Table 1 Authors and the purpose of their studies.

\begin{tabular}{|c|c|}
\hline Authors & Purpose \\
\hline Simonds (1981) & $\begin{array}{l}\text { He collected information about the management accounting of a company and its } \\
\text { competitors used for developing and monitoring business strategy. }\end{array}$ \\
\hline Simonds (1982) & $\begin{array}{l}\text { He approached management accounting with an emphasis on price strategy in relation } \\
\text { to competitiveness. }\end{array}$ \\
\hline Simonds (1986) & $\begin{array}{l}\text { He addressed accounting measurement based on the competitive position in which a } \\
\text { competitor's sales revenue is perhaps the most important of all competitive indicators. }\end{array}$ \\
\hline Jones (1988) & $\begin{array}{l}\text { He discussed the advantages of estimating competitors' costs as a way to improve the } \\
\text { effectiveness of the organization itself. }\end{array}$ \\
\hline Moon and Bates (1993) & $\begin{array}{l}\text { They developed the CORE (Context, Overview, Ratios and Evaluation) structure as } \\
\text { support for interpreting the financial statements for future analysis. }\end{array}$ \\
\hline Subramanian and Ishak (1998) & $\begin{array}{l}\text { They identified in US companies what information on competitor's managers } \\
\text { considered as being a priority. }\end{array}$ \\
\hline Guilding (1999) & He sought to synthesize and list the CFC practices identified in the literature. \\
\hline Heinen and Hoffjan (2005) & $\begin{array}{l}\text { They analyzed the influence of the relative position of costs on strategic decisions to } \\
\text { identify the connection between the knowledge on the costs of competitors and the } \\
\text { success of the company. }\end{array}$ \\
\hline Anderson and Guilding (2006) & They described six criteria that can be used to evaluate competitor analysis. \\
\hline Casella (2008) & $\begin{array}{l}\text { She identified the interconnection between strategic cost management and competitive } \\
\text { intelligence, in which the analysis of competitors' costs is perceived. }\end{array}$ \\
\hline Hesford (2008) & $\begin{array}{l}\text { He investigated the use of accounting information of competitors by individuals acting } \\
\text { in competitive intelligence. }\end{array}$ \\
\hline Bertucci and Milani Filho (2010) & They described the competitor analysis model adopted for pricing. \\
\hline Santos (2010) & $\begin{array}{l}\text { He systematized the knowledge on cost analysis of competitors and investigated the } \\
\text { reality of practices in companies. }\end{array}$ \\
\hline Santos and Rocha (2011) & $\begin{array}{l}\text { They verified the use and the perception of value of the practices of Accounting } \\
\text { Focused on the Competitors in an agribusiness industry. }\end{array}$ \\
\hline Tsai, Chu and Chen (2011) & $\begin{array}{l}\text { They proposed that the way a company is embedded in market engagement } \\
\text { relationships shapes the insight of the company's competitor, suggesting a new } \\
\text { approach to competitor analysis based on rival-centric perceptions. }\end{array}$ \\
\hline Costa and Rocha (2014) & $\begin{array}{l}\text { They identified the elements that characterize the determinants of costs in companies } \\
\text { producing electronics in Brazil. }\end{array}$ \\
\hline $\begin{array}{l}\text { Friedrich, Fontoura, Souza and Wittimann } \\
\text { (2016) }\end{array}$ & $\begin{array}{l}\text { They identified the knowledge and the use of practices of cost analysis of competitors } \\
\text { by companies of the metal mechanic segment of the state of Rio Grande do Sul, Brazil. }\end{array}$ \\
\hline Souza, Borgert and Gasparetto (2016) & $\begin{array}{l}\text { They analyzed the characteristics of scientific research related to the topic of } \\
\text { Competitor Analysis, with the purpose of generating knowledge and identifying gaps } \\
\text { for future research. }\end{array}$ \\
\hline
\end{tabular}

Source: Adapted from Friedrich et al. (2016). 
The gathering of data concerning competitors includes information from suppliers, clients, governmental agencies, commercial associations and professional societies, which when combined, supply data and conditions to estimate competitors' costs (Hesford, 2008). The gathering of data used for the cost analysis is composed of collected information through generally accepted ethical practices. Hitt, Ireland \& Hoskisson (2012) focus that there are legal and non-legal practices for data collection. In relation to legal practices, they are those available to the public through reports and financial statements, annual reports, corporate websites, commercial fairs and expositions. Concerning the illegal practices, some examples are information collected through blackmail, industrial spying, illegal eavesdropping, and project theft, among others. In this paper, we use publicly disclosed financial statements as a source of competitor data.

Jones (1988) analyzed the cost structure of Caterpillar when compared to its competitors. Due to the lack of availability of other forms of information and data, Jones analyzed the published financial statements and estimated the costs with reasonableness. The results suggested that Caterpillar made changes that resulted in a $20 \%$ reduction in total expenses when compared to its competitors (Jones, 1988).

Moon and Bates (1993) developed a framework called Context, Overview, Ratios and Evaluation (CORE). The goals of the CORE model is to: (i) make an assessment of internal and external profiles in which the organization is inserted in (i.e. context); (ii) assess the financial performance and other types of outcome that present possible positive tendencies or significant facts that could distort the analysis (i.e. overview); (iii) interpret the calculated financial ratios as observed in earlier stages (i.e. ratios) and (iiii) make an interpretation of earlier stages in order to address the performance in strategic areas, as well as the implications for its competitors (i.e. evaluation) (Moon \& Bates, 1993). When using the CORE framework, someone is able to analyze the cost structure and competitors' cost in order to make the right strategic decisions.

Guilding (1999) pointed out five main practices involving competitor-focused accounting, such as competitors' cost evaluation, competitive position monitoring, evaluation of competitors through published financial statements, strategic costing and strategic pricing. These five main practices help firms to compete in different areas and make decisions based on published financial statements.

In using the practice by Guilding (1999) of evaluating competitors in published financial statements, we find the work by Casella (2008) in Brazil as a pioneering study, which analyzed four companies in the paper and cellulose industry in Brazil. His research's main goal was to verify the possibility of inferring fixed and variable costs from the competitors, according to the production volume. The results indicated that it was possible to infer the related costs of labor, capital assets, depreciation from the companies and that it was possible to compare the competitors' position in relation to inventory turnover, operational cycle, the degree of operational leverage, expenses with sales, administrative expenses and also cost structures throughout the firms. Casella's (2008) research advances in terms of supporting the practice of competitors' costs evaluation according to the published financial statements.

Hansen and Mowen (2001) suggest estimating the costs by separating the fixed costs from the variable costs with the application of statistical models to infer these costs. Furthermore, Benjamin Junior, Souza and Costa (2015) highlight that the statistical techniques prove to be very efficient in estimating the companies' cost structure, in addition to the numbers published in the financial statements. 


\section{Cost drivers}

Cost drivers are the ones considered as the main drivers. The cost determinant represents the structural cost of an activity that is under the control of a company. In terms of cost determinants, no main driver would be the only one responsible for the cost position of a company (Porter, 1992). As a result, when analyzing the cost determinants, the research should comprehend that in different levels the costs determinants act jointly (Porter, 1992).

The cost driver means the factors that determine the existence (or the absence) of a cost element when defining the cost's superior and inferior limit and its behavior (Souza \& Rocha, 2009). According to literature, a cost driver influences the cost composition of a company (Souza \& Rocha, 2009). A certain degree of quantification/precision to determine the relative importance of each cost determinant makes it easier to build estimates of competitors' cost positions (Porter, 1992).

There is no consensus about the classification of cost determinants since the classification varies according to the number of factors that can have an influence on the firm's costs (Costa \& Rocha, 2012) and consequently on the cost of its competitors.

For the purposes of this study, we use the capital structure of companies and their capital assets as costs determinants. In that sense, these costs determinants are our main drivers. In this context, the first cost determinant is the proportion of the origin of resources, whether it is own capital or third-party capital, which the organization uses to finance its activities. The proportion of the origin of resources is stated as a determinant factor by the fact that the cost of own capital is normally different from the cost of a third party (Souza \& Rocha, 2009).

The second determinant - Capital Asset - can be explained by the diversity of firm's machinery and equipment. The capital asset is the book value of these machines and the general costs related to the acquisition, preservation, and maintenance of machines and equipment (Brealey et al. 2012; Lambert, Leuz \& Verrecchia, 2007).

\section{Previous literature}

According to our review, Table 2 shows the main studies that used a cost strategy in the analysis of profits.

Besides these, three papers represent the main base for establishing our research problem and objectives. In this sense, these papers are presented below. The mains goal of Casella's (2008) study was to demonstrate the possibility of building an analysis of competitors' cost in the paper and cellulose industry through the use of published financial statements. To create the analysis of competitors' cost, Casella used the production volume to calculate the cost structures of the companies. The author concluded that it was possible to infer the competitors' costs based on published financial statements.

The research by Albanez, Bonizio and Ribeiro (2008) sought to identify the representativeness of fixed costs in the set of production costs and operational expenses of the sugarcane industry. Albanez, Bonizio and Ribeiro (2008) concluded that a relevant part of the operational costs and expenses had variable behavior, which was a positive factor for the sugarcane industry to reduce the operational risk of the activity.

Souza (2011), based on published financial statements, sought to estimate the composition of the structure of costs and expenses that had above-average profitability and operating 
profitability in the textile and steel/metallurgical sectors. We calculated the cost concurrent by averaging the composition of fixed costs and expenses and variable costs to total costs and expenses. The results indicated that there is a strong and negative correlation between fixed costs and expenses and the performance indicators used (average operating margin and average operating profitability). Souza (2011) revealed that the cost and expenses structure of the steel industry permit larger participation of fixed costs and expenses than in the textile industry.

Table 2 Studies on the subject

Authors

Guilding (1999)

Heinen and Hoffjan (2005)

Hesford (2008)

Bertucci and Milani Filho (2010)

Santos and Rocha (2011)
Search

He conducted a study in 112 companies in New Zealand, aiming to synthesize accounting practices. The author proposed four factors (strategic mission, competitive strategy, size and type of company) that may affect an adoption rate and a perception of the aid over practices. A more observed practice was the monitoring of the competitive position.

They identified a positive correlation between company performance and the use of competitor cost analysis. It is an experiment formed through business games, in which they identified: i) that there are not many studies that deal with the importance of analyzing the cost of competitors; ii) Competitor cost analysis can be an important tool to maintain or gain competitive advantage; and iii) their knowledge allows anticipating future behavior.

He interviewed 23 people with competitive intelligence (CI), randomly selected from 16 industries. He identified that the more market-orientedthe organization is and developed in terms of CI (competitive intelligence), the more accounting information is used to estimate the cost of competitors.

They described a model of wiring analysis adopted for the decision-making by companies with production to order. It is a demonstration that this approach is responsible and uses managers to understand the competitive advantages of the company over its competitor and its actions on the critical elements of costs.

A study done in a multinational company in Brazil. The research highlighted: i) the use and perception of the usefulness of monitoring the competitive position of the competitor based on published accounting statements; ii) it does not make use of nor does it perceive utility in the strategic costing and the evaluation of the costs of competitors; iii) assigns value to the CFC practices of which it is used; and iv) main reason for not using reverse engineering is the legal issue.

Source: Adapted from Friedrich et al. (2016).

\section{Methodology design}

This research is characterized as descriptive (McNichols, 2000). This paper is also characterized as an empirical-analytical research since studies of this nature present common collection, quantitative treatment and analysis of data, which favors practical investigations (Fields, Lys \& Vincent, 2001). 
Based on the discussion brought in the theoretical foundation, we intended to apply an analysis on the competitors' costs of the sugarcane industry. Our main focus was to use companies that possess the level of corporate governance classified as New Market according to the BMF\&BOVESPA(2015b). This New Market criterion represents a bigger level of corporate governance and consequently a larger reliance and transparency of financial statements. As a consequence of this New Market criterion, we can generate homogenous information to be used in the analysis of the competitors' costs in the sugarcane industry. The criterion of homogeneity in the level of Initial Public Offering (IPO) (New Market) is a differential according to prior studies (Casella, 2008).

In terms of the sample, we found five companies linked to the sugarcane industry, such as Biosev S.A., CosanLimitada, Cosan S.A., RaizenEnergia and São Martinho S.A. However, only three of them possess BMF\&BOVESPA's New Market corporate governance level. They are Biosev S.A., Cosan S.A. and São Martinho S.A. These three companies compose the sample for this study. We analyzed the data according to these three companies. In addition, we used a global analysis in which we aggregate the overall results.

We collected data through documental research in the Economatica and Fundamentus databases. These databases present information on stock markets, government bonds, the fund industry and various indicators. We extracted the data from quarterly Balance Sheets and Income Statements of the investigated companies. "Material published about competitors can be examined and information from commercial data bases can be utilized. However, compared to these publicly accessible sources, third parties such as, individual industry experts, are considered more valuable" (Guilding, 1999, p.19).

We confronted the data to verify if the values of all variables were the same, as well as if the data were complete for the analyzed period (2007-2016). After this verification and data certification, we noted that one of the companies did not disclose its information on all analyzed years. Biosev had a Public Offering in 2013 for the second time in its history (Souza, 2013). Even so, we decided to keep the Biosev Company in our sample for the period from 2012 to 2016 because our main focus is to analyze the concurrent cost.

The statistical techniques used in this paper were regression and correlation. We used two regression models, one for the verification of the impact of variable costs on CGS (first research question) and another model to verify the relation between the cost determinants and the CGS (second research question).

We used the cost of goods sold (CGS) as the dependent variable in the two regression models and collected its value in the Income Statements. The explanatory variables were REVENUE (REV), used as a production volume proxy obtained in the Income Statement; the capital assets (CAPASSETS), composed of property, plant and equipment, obtained in the Balance Sheet; and capital structure, composed of two ratios: total debt ratio and the equity ratio (DTDE) calculated by the division of the total liabilities and the total of liabilities plus stockholders' equity, and debt to equity ratio (DER) which is calculated by the division of the total liabilities and the stockholders' equity. 


\section{Results presentation and analysis}

Table 3 shows the descriptive results of the variables. The total number of valid cases were 105 observations made up of quarterly information from the 2007-2017 period for the following companies, Cosan and São Martinho. In addition, we used the 2012-2017 period for Biosev Company. The missing values were two observations, since the information was not published. We analyzed the variables through the mean and standard deviation. Pearson's correlation matrix shows the association value between one variable and another. According to the values, the CGS presents significant correlation with revenue $(r=.98 ; p<.001)$, and capital assets $(r=.28 ; p<.001)$.

The correlation between the CGS and revenue can be explained by the fact that the CGS alone is a component of revenue and that the capital assets can be considered as a part of the fixed costs, which is a component of the CGS. Souza (2011) used the capital assets as a proxy for fixed costs and expenses in his model.

Table 3 Descriptive analysis of variables

\begin{tabular}{lcccccc}
\hline Variables & Mean & $\begin{array}{c}\text { Standard } \\
\text { Deviation }\end{array}$ & 1 & 2 & 3 & 4 \\
\hline 1. REV-Revenue & 1949919 & 3145592 & 1 & & & \\
2. CGS-Cost of Goods Sold & 1609533 & 2834890 & $.98^{* *}$ & 1 & & \\
3. CAPASSETS-Capital Assets & .67 & .15 & $.28^{* *}$ & $.30^{* *}$ & 1 & \\
4. DT/DE-Total debt ratio plus equity ratio & -.52 & 16.62 & .07 & .06 & .13 & 1 \\
5. DER-Debt to equity ratio & .26 & .08 & .01 & .02 & -.02 & $-.33^{* *}$ \\
\hline
\end{tabular}

Source: research data. $\mathrm{N}=105$ valid cases

The regression model used in this paper aims to compare the influence of the variable and fixed costs on the composition of the CGS. To this end, the following equation (1) shows the set of points $\left(\mathrm{x}_{\mathrm{i}}, \mathrm{y}_{\mathrm{i}}\right)$ :

$$
y=a+b x+e
$$

Where $\alpha$ indicates the intercept of the line with the $Y$-axis and $\beta$ being the angular or inclination coefficient of the straight-line equation. In other words, $\alpha$ indicates in the proposed model the intercept of the line represented by the fixed costs kept constant. B represents the angular or inclination coefficient of the straight-line, which is the variable cost being measured by revenue multiplied by a sold value. This regression model follows the procedures suggested by Albanez, Bonízio and Ribeiro (2008).

Our regression model assumes that the revenue influences the variable cost. Therefore, the greater the beta value, the greater the impact of revenue on the cost of goods sold. Thus, the beta coefficient shows the impact of the variable cost (proportionally). We estimated four regressions models. One regression model uses the global results of aggregate companies and three other regressions models use each competitor separately.

We used the time series data as the covariate. We recoded the time series data as a dummy 
for each year (2007-2016). We regressed this dummy variable in order to verify its influence of time series data on the cost of goods sold. As a result, the findings suggest the effects of fixed costs and revenues beyond time series information. The procedure of using time series data as a covariate is according to Gujarati (2009).

According to the data presented in Table 4, the intercept in the Biosev Company presents a value of 708000.5. The intercept refers to the fixed cost. In addition, in the Biosev company the revenue beta of $\beta=.48(p<.10)$ had a marginal and significant effect on the cost of goods sold. When we compare the coefficient values with other companies and show the significant values, we support our assumption that it is possible to compare the concurrent costs across firms.

We also presented statistical information about the Schwarz criterion (it is a criterion for model selection among a finite set of models), Hannan-Quinn criterion (it is an alternative to the Akaike information criterion) and Durbin-Watson (statistic to detect the presence of autocorrelation at lag 1 in the residuals). This statistical information is according to Maïnassara and Kokonendji (2016).

The Cosan S/A company presented a constant of $-502767.8(p<.01)$ and the effect of revenue was $\beta=.91 \quad(p<.01)$. The Sao Martinho company also showed a significant effect of revenue $(\beta=.59 ; p<.01)$. These results across companies support the main idea that the concurrent costs are comparable across competitors. We also combined all samples to create a global analysis. The global analysis showed that the effect of revenue was significant $(\beta=.89 ; p<.001)$.

Another point to be analyzed is the operational leverage, which in Biosev is stronger. As the constant is the intercept of the curve, represented here by the fixed cost. The higher the fixed cost, the greater the risk to the company in terms of market operation due to the operational leverage.

Table 4 Comparative regression analysis of companies' costs

\begin{tabular}{|c|c|c|c|c|}
\hline Variables & Biosev & Cosan S/A & São Martinho & Global \\
\hline Year 2007 & & & 1710.413 & $242403.7 *$ \\
\hline Year 2008 & & $457599.5^{* * * *}$ & -8353.461 & $218253.0^{* * *}$ \\
\hline Year 2009 & & $370822.5^{* * * *}$ & 6377.232 & $198847.7 *$ \\
\hline Year 2010 & & $213126.0^{*}$ & -21867.90 & 108727.5 \\
\hline Year 2011 & & 188584.1 & -9295.479 & 116581.0 \\
\hline Year 2012 & -277880.4 & $313491.4^{* *}$ & 15644.55 & $207755.3 * *$ \\
\hline Year 2013 & -252382.6 & 57328.59 & 2208.958 & $146446.2 \dagger$ \\
\hline Year 2014 & -417397.7 & 79871.46 & -9921.018 & 49271.24 \\
\hline Year 2015 & -322403.8 & 39704.84 & $29713.30 \dagger$ & -17531.86 \\
\hline Year 2016 & -11920.64 & -85167.39 & $37777.68 *$ & -9650.110 \\
\hline Revenue & $0.480458 \dagger$ & $0.919979 * *$ & $0.599711 * * *$ & $0.897049 * * *$ \\
\hline Constant (Fixed Cost) & 708000.5 & $-502767.8 * *$ & 48241.55 & $-240116.9 * * *$ \\
\hline Schwarz criterion & 27.80378 & 27.21648 & 23.24264 & 27.45433 \\
\hline Hannan-Quinn criter. & 27.53117 & 26.91997 & 22.92814 & 27.27170 \\
\hline Durbin-Watson stat & 2.191536 & 2.312216 & 2.246282 & 1.255963 \\
\hline
\end{tabular}


Total panel (unbalanced)

observations

$\begin{array}{lllll}\text { Included Observations } & 21 & 40 & 42 & 43 \\ \text { R-squared } & 0.786706 & 0.999125 & 0.982514 & 0.996464 \\ \text { Adjusted R-squared } & 0.695295 & 0.998824 & 0.976103 & 0.996036 \\ \text { S.E. of regression } & 194514.8 & 139089.8 & 18707.24 & 179903.9 \\ \text { Sum squared resid } & 5.30 \mathrm{E}+11 & 5.61 \mathrm{E}+11 & 1.05 \mathrm{E}+10 & 2.95 \mathrm{E}+12\end{array}$

Source: research data.

Note: $* * p<.01 ; * p<.05 ; \dagger p<.10$.

Table 5 Comparative Regression analysis of the companies' costs.

\begin{tabular}{|c|c|c|c|c|}
\hline Variables & Biosev & Cosan S/A & São Martinho & Global \\
\hline Year 2007 & & & $-436114.8 * *$ & -183079.7 \\
\hline Year 2008 & & -298935.6 & $-408972.9 * *$ & -250556.5 \\
\hline Year 2009 & & 2804941 . & $-333562.5^{*}$ & 542941.5 \\
\hline Year 2010 & & 4147218. & $-318168.3 *$ & 773718.2 \\
\hline Year 2011 & & 5851912. & $-287084.0 *$ & 901868.7 \\
\hline Year 2012 & -1494185 & 6739731 & $-290655.4 * *$ & 930325.3 \\
\hline Year 2013 & -1544305 & $8365951 . *$ & $-284568.6^{*}$ & 2372361.* \\
\hline Year 2014 & -1138992 & 390887.0 & $-344845.1 * *$ & -65015.63 \\
\hline Year 2015 & -391911.6 & 101111.6 & -196709.0 & 163560.8 \\
\hline Year 2016 & -299457.1 & -186331.9 & -96365.85 & 30759.99 \\
\hline DER Debt to equity & .718007 & -0.292227 & -0.057562 & $0.342304^{*}$ \\
\hline $\mathrm{DT} / \mathrm{DE}$ & -2713855 & -16373818 & -1693106 & 1343680 . \\
\hline CAPASSETS & -1346.80 & 1947723. & $444226.6^{*}$ & 5159.159 \\
\hline Constant (Fixed Cost) & 1631078 & 8397997. & $1091340 *$ & -953990.9 \\
\hline Schwarz criterion & 27.98 & 33.90805 & 25.39343 & 33.01107 \\
\hline Hannan-Quinn criter. & 27.63 & 33.55763 & 25.02652 & 32.79800 \\
\hline Durbin-Watson stat & 2.59 & 2.304810 & 2.588310 & 1.492471 \\
\hline Total panel (unbalanced) observations & & & & 103 \\
\hline Included Observations & 21 & 40 & 42 & \\
\hline R-squared & .80 & 0.414176 & 0.874264 & 0.163010 \\
\hline Adjusted R-squared & .68 & 0.153810 & 0.815887 & 0.040753 \\
\hline S.E. of regression & 198717.5 & 3730920. & 51925.51 & 2798686. \\
\hline Sum squared resid & $4.74 \mathrm{e}+11$ & $3.76 \mathrm{E}+14$ & $7.55 \mathrm{E}+10$ & $6.97 \mathrm{E}+14$ \\
\hline
\end{tabular}

Source: research data.

Note: $* * \mathrm{p}<.01 ; * \mathrm{p}<.05 ; \uparrow \mathrm{p}<.10$. 
The main of the second regression analysis was to verify the relation of the capital assets and the capital structure with the CGS. For such purpose, we applied the multivariate equation 2 to present the set of points $\left(\mathrm{x}_{\mathrm{i}}, \mathrm{y}_{\mathrm{i}}\right)$ :

$$
\mathrm{y}=\alpha+\beta 1_{\mathrm{x} 1}+\beta 2_{\mathrm{x} 2}+\ldots+\varepsilon
$$

Where $\alpha$ indicates the line intercept with the $Y$-axis; $\beta 1, \beta 2$ and $\beta 3$ are the angular coefficients of the straight-line; $x 1$ is the capital asset variable; $x 2$ is the total debt ratio plus the equity ratio, and $x 3$ is debt to equity ratio.

The results are described in a way that compares the three competitors. Table 5 summarizes the data analysis. The first finding is that the variable DER Debt to equity was significant in the global model $(\beta=.34 ; p<.01)$. In this sense, this variable can be considered determinant in the CGS for the competing companies in a global form.

\section{Additional analysis}

In Table 6, we estimate all the data again by using an econometric model. Specifically, we estimate the information using panel data.

Table 6 Panel data fixed effects

\begin{tabular}{lll}
\hline Variables & Global & Global \\
Revenue & $.91 * * *$ & \\
Constant (fixed costs) & $-183931.1 * * *$ & $.42^{* *}$ \\
DER Debt to equity & & 1475901. \\
DT/DE & & -268.30 \\
CAPASSETS & & -792405.7 \\
Constant (fixed costs) & & 0.308971 \\
R-squared & 0.996812 & 0.273351 \\
Adjusted R-squared & 0.996716 & 2435853. \\
S.E. of regression & 163757.1 & $5.76 \mathrm{E}+14$ \\
Sum squared resid & $2.65 \mathrm{E}+12$ & -1657.758 \\
Log likelihood & -1380.743 & 8.674094 \\
F-statistic & 10319.76 & 0.000001 \\
Prob(F-statistic) & 0.000000 & \\
\hline
\end{tabular}

Source: research data.

Note: $* * p<.01 ; * p<.05 ; \dagger p<.10$.

Panel data uses longitudinal data or cross-sectional time series data to analyze the influence of some variables in others. In addition, panel data can control the effect of longitudinal data, which is our case. In that sense, we used fixed effect assumption, which suggests that the individual-specific effects of our variable are correlated with the independent variables (Baltagi, 1995). 
The fixed effect panel is because although the intercept may differ between companies, the intercept of each individual does not vary with time. As a conclusion, the intercept of each individual is invariant across time. According to the findings, fixed costs $(\mathrm{c}=-183931.1)$ and revenue $(\beta=.01 ; p<.001)$ influenced the CGS in a global form. In addition, we also find a significant value for DER debt to equity $(\beta=.42 ; p<.01)$ in effecting the CGS.

\section{Conclusions}

According to Bromwich (1990, p. 27), "there is a need for accountants to consider the cost structure of not only their own firm but of all enterprises in the relevant market and of potential entrants. It also suggests that costs cannot be considered in isolation from demand factors". With a high level of competitiveness existing in the corporate environment, strategic cost management, through the artifact of competitors' cost analysis, can be a differential in the search for competitive advantage. The present research used the competitors' cost analysis taking into account the publicly disclosed financial statements of companies from the sugarcane industry. The main goal was to analyze the impact of the variable costs in the CGS and verify the relation between the determinants of capital structure and capital assets on the CGS.

According to the data analysis, we reached the set objectives and answered the two research questions of this paper. The first question was "What is the impact of the variable costs on the cost of goods sold, keeping a steadily fixed cost, in competing companies of the sugarcane industry in the period from 2007 to 2016?". The results suggested that the variable costs had more proportion in the cost structure of Biosev (65\% of the CGS) and of Cosan (99\% of the CGS), as for São Martinho (97\% of the CGS). The data of COSAN S/A had negative values (negative costs) and for this reason, the cost analysis of this company was impaired.

Second, the next question was "What is the relation of capital structure and capital assets with the cost of goods sold of the analyzed companies"? It had been suggested that CAPASSETS and DER Debt to equity were the two determinants that had influenced the CGS. The capital assets and the total debt ratio plus the equity ratio had direct relation and the debt to equity ratio presented an inversely proportional relation.

Third, the results discussed in this study cannot be compared to the other investigations that use different information and data. In relation to the research by Souza (2011) in the steel industry, the findings indicated that the proportion of fixed costs was from $30.34 \%$ to $30.60 \%$. In addition, in the textile industry, the findings indicated that the proportion of fixed costs was between $20.15 \%$ and $20.76 \%$. In this paper, the fixed costs of Biosev and Cosan S/A can were compared to Souza (2011).

One limitation of this study concerns the period of data collection for Biosev. The time series data was shorter than for the other companies. Future research should carry on with competitors' costs analysis in sectors that have not yet been researched through published financial statements and by the use of other cost determinants, as suggested by Costa (2011). 


\section{References}

Albanez, T., Bonizio, R. C., \& Ribeiro, E. M. S. (2008). Uma análise da estrutura de custos do setor sucroalcooleiro brasileiro. Custos e Agronegócio, 4(1), 79-102.

Anderson, S., \& Guilding, C. (2006). Competitor-focused accounting applied to a hotel context. International Journal of Contemporary Hospitality Management, 18(3), 206-218. https://doi.org/10.1108/09596110610658616

Ansari, S. L. (Ed.). (1997). Target costing: the next frontier in strategic cost management. Irwin Professional Publishing.

Baltagi, B. H. (1995). Econometric analysis of panel data (Vol. 2). New York: Wiley.

Bertucci, C. E., \& Milani Filho, M. A. F. (2010). Análise de custo de competidores em tomadas de preço: estudo de caso em uma empresa multinacional. In 17 Congresso Brasileiro de Custos (pp. 1-15). Belo Horizonte: ABCustos.

Benjamin Junior, V. B., Souza, R. P., \& Costa, S. A. (2015). Estrutura de Custos: um enfoque utilizando dados em painel. Contabilometria. Brazilian Journal of Quantitative Methods Applied to Accounting, 2(1), 54-69.

Bhimani, A., \& Keshtvarz, M. (1999). British management accountants: strategically oriented. Journal of Cost Management, 13(2), 25-31.

Bm\&FBovespa (2015a). Derivativos e Commodities. Avaliable in: http://www.bmfbovespa.com.br/pt-br/educacional/ cursos/derivativos /commodities.aspx?Idioma=pt-br .

Bm\&F Bovespa (2015b). Novo Mercado. Avaliable in: http://www.bmfbovespa.com.br/cias-listadas/empresas-listadas/BuscaEmpresa Listada.aspx?idioma=pt-br .

Brealey, R. A., Myers, S. C., Allen, F., \& Mohanty, P. (2012). Principles of corporate finance. Tata McGraw-Hill Education.

Bromwich, M. (1990). The case for strategic management accounting: the role of accounting information for strategy in competitive markets. Accounting, Organizations and Society, 15(1-2), 27-46. https://doi.org/10.1016/03613682(90)90011-i

Casella, B. M. B. X. (2008). Análise de custos de concorrentes: estudo exploratório no setor de celulose e papel. (Dissertação de Mestrado), Faculdade de Economia, Administração e Contabilidade (FEA/USP), Universidade de São Paulo.

Cavalluzzo, K. S., Cavalluzzo, L. C., \& Wolken, J. D. (2002). Competition, small business financing, and discrimination: Evidence from a new survey. The Journal of Business, 75(4), 641-679. https://doi.org/10.2139/ssrn.171733

Cooper, R. \& Slagmulder, R. (1998). Strategic cost management: what is strategic cost management? Management Accounting, 79 (7), 14-16.

Cooper, R. \& Slagmulder, R. (2003). Strategic cost management: expanding scope and boundaries. Journal of Cost Management, 17(1), 23-30.

Cooper, R. \& Slagmulder, R. (2004). Cost analysis outside the organization. Cost Management, 18 (3), 44-46, May/ June.

Costa, S. A. D. (2011). Análise de custos de concorrentes: um estudo dos determinantes de custos no setor de eletroeletrônicos. (Tese de Doutorado), Faculdade de Economia, Administração e Contabilidade (FEA/USP), Universidade de São Paulo.

Costa, S. A., \& Rocha, W. (2012). Determinantes de custos de concorrentes: identificação a partir de informações públicas. In: XIX Congresso Brasileiro de Custos, Bento Gonçalves, RS, Brasil.

Dawson, S., Mole, V., Winstanley, D., \& Sherval, J. (1995). Management, competition and professional practice: medicine and the marketplace. British Journal of Management, 6(3), 169-181. https://doi.org/10.1111/j.1467-8551.1995. tb00092.x

Dixon, R. (1998). Accounting for strategic management: a practical application. Long Range Planning, 31(2), 272-279. https://doi.org/10.1016/s0024-6301(98)00011-9

Ferraz, J. C., Kupfer, D., \& Haguenauer, L. (1995). Made in Brazil: desafios competitivos para a indústria. Rio de Janeiro: Campus.

Fields, T. D., Lys, T. Z., \& Vincent, L. (2001). Empirical research on accounting choice. Journal of accounting and economics, 31(1-3), 255-307. https://doi.org/10.2139/ssrn.258519 
Friedrich, L. R., Fontoura, F. B. B., Souza, M. A., \& Wittimann, M. L. (2016). Análise da utilização do custo de concorrentes: um estudo em empresas do setor metal mecânico do Estado do Rio Grande do Sul - Brasil. Revista Espacios, 37(20), 27.

Guilding, C. (1999). Competitor-focused accounting: an exploratory note. Accounting, Organizations and Society, 24(7), 583-595. https://doi.org/10.1016/s0361-3682(99)00007-0

Guilding, C., Cravens, K. S., \& Tayles, M. (2000). An international comparison of strategic management accounting practices. Management Accounting Research, 11(1), 113-135. https://doi.org/10.1006/mare.1999.0120

Gujarati, D.N. (2009). Basic econometrics. Tata McGraw-Hill Education.

Hansen, Don R.; \& Mowen, Maryanne M. (2001)Gestão de custos: contabilidade e controle. São Paulo: Pioneira Thomson Learning.

Heinen, K. C., \&Hoffjan, A. (2005). The strategic relevance of competitor cost assessment-An empirical study regarding competitor accounting. Journal of Applied Management Accounting Research, 3(1), 17-34.

Hesford, J. W. (2008). An empirical investigation of accounting information use in competitive intelligence. Journal of Competitive Intelligence and Management, 4(3), 17-49.

Hitt, M. A., Ireland, R. D., \& Hoskisson, R. E. (2012). Strategic management cases: competitiveness and globalization. Cengage Learning: Boston MA.

Jones, L. (1988). Competitor cost analysis at Caterpillar. Management Accounting, 70(4), 32-38.

Lambert, R., Leuz, C., \& Verrecchia, R. E. (2007). Accounting information, disclosure, and the cost of capital. Journal of Accounting Research, 45(2), 385-420. https://doi.org/10.1111/j.1475-679x.2007.00238.x

Laseter, T.M., Heckel, K., \& Huang, A. (2017). Competitive Cost Analysis: Cost Driver Framework. University of Virginia. Darden Business School. Case No. UVA-OM-1254. 1-10.

Lord, B. R. (1996). Strategic management accounting: the emperor's new clothes? Management Accounting Research, 7(3), 347-366. https://doi.org/10.1006/mare.1996.0020

Maïnassara, Y. B., \& Kokonendji, C. C. (2016). Modified Schwarz and Hannan-Quinn information criteria for weak VARMA models. Statistical Inference for Stochastic Processes, 19(2), 199-217. https://doi.org/10.1007/s11203015-9123-Z

McNichols, M. F. (2000). Research design issues in earnings management studies. Journal of Accounting and Public Policy, 19(4-5), 313-345.

Moon, P., \& Bates, K. (1993). Core analysis in strategic performance appraisal. Management Accounting Research, 4(2), 139-152. https://doi.org/10.1006/mare.1993.1009

Porter, M. E. (1992). Vantagem competitiva: criando e sustentando um desempenho superior. Rio de Janeiro: Campus. Porter, M. E. (2008a). Competitive strategy: Techniques for analyzing industries and competitors. Simon and Schuster.

Porter, M. E. (2008b). The five competitive forces that shape strategy. Harvard Business Review, 86(1), 25-40. https:// doi.org/10.1007/978-1-349-20317-8_10

Santos, R. P. (2010). Análise dos custos concorrentes: um estudo exploratório entre teoria e prática. (Dissertação de Mestrado). Universidade de São Paulo, São Paulo.

Shank, J. K. (1989). Strategic cost management: new wine, or just new bottles. Journal of Management Accounting Research, 1(1), 47-65.

Shank, J. K., \& Govindarajan, V. (1989). Strategic cost analysis: the evolution from managerial to strategic accounting. McGraw-Hill/Irwin.

Simmonds, K. (1981). Strategic management accounting. Management Accounting (UK), 59(4), 26-29.

Simmonds, K. (1982). Strategic management accounting for pricing: a case example. Accounting and Business Research, 12(47), 206-214. https://doi.org/10.1080/00014788.1982.9728809

Simmonds, K. (1986). The accounting assessment of competitive position. European Journal of Marketing, 20(1), 1631. https://doi.org/10.1108/eum0000000004626

Souza, B. (2013). Biosev estreia na Bovespa com forte queda de 13\%. Revista Exame (online). Avaliable in: http:// exame.abril.com.br/mercados/noticias/biosev-estreia-na-bovespa-com-forte-queda-de-13. Access: 28/07/2015.

Souza, B. C. (2011). Relação da estrutura de custos e despesas com a rentabilidade e lucratividade operacional nos setores têxtil e siderúrgico/metalúrgico no Brasil no período de 2005 a 2009. (Tese de Doutorado), Faculdade de Economia, Administração e Contabilidade (FEA/USP), Universidade de São Paulo. 
Souza, B. C., \& Rocha, W. (2009). Gestão de custos interorganizacionais. São Paulo: Atlas.

Souza, F. F., Borgert, A., \& Gasparetto, V. (2016). Análise de concorrentes: oportunidades baseadas em pesquisas em contabilidade. Revista Capital Científico, 14(4).

Souza, M. A., Marengo, S., \& Jaroseski, S. (2012). Adoção de práticas de gestão externa de custos: um estudo multicaso em empresas da região da serra gaúcha. Revista Universo Contábil, 8(2), 43-63. https://doi.org/10.4270/ ruc. 2012212

Subramanian, R., \& Ishak, S. T. (1998). Competitor analysis practices of US companies: an empirical investigation. Management International Review, 38(1), 7-23.

Vidal, M. D. F., Santos, J. D., \& Santos, M. D. (2006). Setor sucroalcooleiro no Nordeste brasileiro: estruturação da cadeia produtiva, produção e mercado. XLIV Congresso da Sociedade Brasileira de Economia e Sociologia Rural $-S O B E R$. Fortaleza-CE.

Vieira, M. C. A.; Lima, J. F.; \& Braga, N. M. (2007). Setor sucroalcooleiro brasileiro: evolução e perspectiva. BNDES. Avaliable in: http://www.bndes.gov.br/SiteBNDES/export/sites/default/bndes_pt/Galerias/Arquivos/conhecimento/liv_perspectivas/07.pdf . Access: 20.06.2015.

Tsai, W., Su, K., \& Chen, M. (2011). Seeing through the eyes of a rival: competitor acumen based on rival-centric perceptions. The Academy of Management Journal, 54(4), 761-778. https://doi.org/10.5465/amj.2011.64870138 